\title{
O ceticismo em Edmund Burke e os pilares do conservadorismo moderno
}

\author{
Skepticism in Edmund Burke and the pillars of modern conservatism
}

\section{Marcos Paulo Quadros}

Coordenador de Graduação da Faculdade da Serra Gaúcha e Pesquisador do Centro de Análises Econômicas e Sociais marcosrq@hotmail.com

Resumo: O artigo investiga o pensamento de Edmund Burke, conferindo especial atenção ao ceticismo político como elemento central de sua filosofia política conservadora. A pesquisa detém-se especialmente no exame da obra seminal do autor, Reflections on the Revolution in France, e nas contribuições de autores referenciais que interpretaram $o$ conservadorismo e as ideias burkeanas. Embora sugira que valores como tradição, defesa da ordem, hierarquia, comunitarismo e oposição ao racionalismo sejam ingredientes importantes para os argumentos de Burke, o artigo sustenta que o ceticismo político seria o grande pilar do conservadorismo, o qual permanece presente no moderno pensamento conservador.

Palavras Chaves: Edmund Burke, conservadorismo, ceticismo político.

\begin{abstract}
This article explores the thought of Edmund Burke, with special attention to political skepticism as a central element of his conservative political philosophy. The research focuses particularly on Burke's most important work, Reflections on the Revolution in France, besides examining the contributions of authors who interpreted conservatism and Burke's ideas. Although it suggests that values such as tradition, defense of order, hierarchy, communitarianism and rejection of rationalism are important to the arguments of Burke, the article argues that political skepticism seems to be the great pillar of modern conservatism, which remains in modern conservative thought.
\end{abstract}

Keywords: Edmund Burke, conservatism, political skepticism. 


\section{Introdução}

A cosmovisão ocidental transformou-se bastante desde o dia em que os agitadores jacobinos, tomados pelo triunfo fulminante das suas ideias radicais, cometeram o regicídio na França setecentista. O locus que serviu de palco à revolução que simbolizaria o ocaso de uma Era não poderia ser mais paradigmático. A França, até então batizada como "filha dileta" da Igreja Católica, abrigava uma monarquia tradicionalíssima, que no Direito Divino dos Reis uma vez buscara sua inspiração e uma das fontes mais caras de sua legitimidade:

Há muito que havia em França um culto pelo rei, o único monarca europeu que se podia vangloriar de ter sido ungido com óleos vindos diretamente dos céus, o herdeiro de Carlos Magno, a esperança dos doentes. [...] A França era a terra santa, onde floresciam a piedade, a justiça e o saber. Como antigamente os israelitas, os franceses constituíam um povo eleito, merecedor e objeto do favor divino (STRAYER, 1986: 60).

Com efeito, a França que atentou para a doutrinação de Bossuet e Bodin contemplou o próprio Papa Leão III coroando Carlos Magno como timoneiro do Sacro Império em uma noite natalina do ano 800. Selava-se então uma aliança entre instituições divinas e seculares que se tornou modelar para os arquitetos dos Estados europeus por séculos. Não obstante, a França de Luís IX - o rei cruzado que recebeu as honras da canonização -, a França das ordens cavalarianas, da nobreza cortesã e das mutualidades das guildas, ouviu um lema inteiramente novo naquele verão de 1789.

As implicações do célebre movimento excederam muito a idealista tríade Liberté, Égalité, Fraternité, influenciando a queda paulatina de monocracias, a supressão dos privilégios de nascimento, a separação radical entre as prerrogativas de Deus e as de César. Mais do que isso, o sopro revolucionário forjaria uma nova mentalidade, avessa aos antigos acervos de pensamento que se moldaram na antiguidade e frutificaram na Idade Média. Se a França foi a nação preferida da Igreja Católica durante mil anos, a revolução jacobina tornou-se a filha dileta daquele iluminismo que Kant classificou, não sem indisfarçado entusiasmo, como "a saída do homem da sua menoridade" (KANT, 1989: 11). 
No bojo deste processo estava a vanguarda da intelectualidade ocidental, que então labutava insistentemente para emancipar o homem das autoridades eclesiásticas assim como Maquiavel, o florentino, havia emancipado a política da teologia moral. As respostas para as inquietações humanas passaram a residir na ciência, e não nos textos sagrados. A consulta aos verbetes da encyclopédie tornou-se mais receitada do que a leitura dos evangelhos. Ante a fé incondicional na infalibilidade do trono de Pedro ${ }^{1}$, ergueu-se a dúvida metódica da qual desde Descartes se fazia propaganda. A busca constante pelo paraíso condicionado ao post mortem cedeu lugar à perseguição do progresso, o deus nascente: a felicidade e a bonança não estão reservadas para uma existência futura, podendo ser desfrutadas em pleno mundo material, no tempo presente. Emergia uma nova promessa salvífica embasada pela "gnose" moderna (VOEGELIN, 1982).

Se a Queda da Bastilha consumou o ápice dessa ruptura psicológica, cultural e política, os atos de Robespierre e seus asseclas paradoxalmente impulsionaram o nascimento de uma visão política cujos princípios seriam intrinsecamente opostos aos revolucionários em tudo o que importa. A revolução - e, em última análise, boa parte dos valores iluministas - encontraria um encarniçado inimigo: o conservadorismo. Em face disso, o presente artigo objetiva examinar as bases do pensamento conservador presentes na produção do escritor irlandês Edmund Burke, contemporâneo da revolução.

Compreender a obra de Burke (e, em particular, o papel do ceticismo em seu pensamento) contribui para clarificar o ethos central de inúmeros conservadorismos formatados a posteriori. Embora seja evidente que tais ideologias não se restrinjam ao terreno da abstração filosófica e, frequentemente, influenciem decisivamente a práxis política de diversos países nos dias que correm, o exame do pensamento conservador - e também de seu founding father - não costuma merecer a atenção que seria desejável por parte dos estudiosos das Ciências Humanas no Brasil. As linhas que seguem, ainda que modestamente, almejam contribuir para minimizar essa lacuna.

\footnotetext{
${ }^{1}$ Empregamos o termo "infalibilidade" apenas para expressar o prestígio então conferido ao papado. Não se quer fazer alusão ao dogma católico da infalibilidade, publicado apenas em 1870 por Pio IX.
} 


\section{Edmund Burke e a gênese dos valores conservadores}

A despeito da pluralidade inerente ao(s) conservadorismo(s), é razoável assinalar que o leitmotiv desta concepção foi justamente a reação à revolução francesa e ao próprio sistema axiológico por ela germinado. De igual modo, Edmund Burke (1729-1797) é amplamente reconhecido como genitor do conservadorismo político moderno, e, "por paradoxal que possa parecer, o pensamento político da época moderna começa por este conservador" (WEFFORT, 1989: 9).

Não obstante, sua obra pouco sistematizada dificulta qualquer diagnóstico. Alheio à técnica e à metodologia, Burke constrói seu pensamento de forma dispersa e ao sabor dos acontecimentos que o afligiam. Maria D'Alva Kinzo assegura que "Burke não escreveu um tratado sobre teoria política; [...] e seu pensamento, embora altamente imaginativo, é bastante assistemático, o que tornou sua produção sujeita a interpretações conflitantes" (KINZO, 1989: 15). Ainda destacando essa particularidade, Parkin reitera que a produção burkeana é "uma exposição acima de tudo assistemática, desordenada e turbulenta" (PARKIN, 1965: 121), que reclama capacidade de discernimento por parte daqueles que ambicionam interpretá-la.

Apesar de tais entraves, o esforço é imperativo. Se em sua primeira publicação, $A$ Vindication of Natural Society: a view of the miseries and evils arising to mankind from every species of artificial society (1756), Burke chegou a ser apressadamente associado à "primeira expressão moderna do anarquismo racionalista e individualista" (ROTHBARD, 1958: 14) $)^{2}$ A Philosophical Enquiry into the Origin of Our Ideas of the Sublime and Beautiful, obra publicada no ano seguinte, começa a revelar com clareza os valores conservadores. O autor introduziu no livro pressupostos que se tornariam basilares para o pensamento conservador: a crítica ao racionalismo e o apreço pelo ceticismo.

Com efeito, "racionalismo em matéria de religião, racionalismo em matéria de política, nada lhe inspirava mais repugnância, nem temor” (CHEVALIER, 1966: 182). Esta expressão do pensamento de Burke é examinada também por Ryan:

\footnotetext{
${ }^{2} \mathrm{O}$ próprio Edmund Burke trata de desfazer a cogitação, redigindo um prefácio na edição posterior do livro no qual define seu conteúdo como uma inequívoca sátira. Realmente, Quinton observa que o trabalho de Burke "é um irônico ataque contra o deísmo de Bolingbroke" (QUINTON, 1976: 38). Rothbard está entre os raros leitores que insistem em visualizar no livro um autêntico manifesto de cunho anarquista.
} 
A compreensão teleológica e kantiana da teoria estética do século XVIII britânico é em grande parte o resultado da posição central que tem sido dada ao seu mais famoso teórico, Edmund Burke. [...] Burke é, em alguns aspectos, o menos kantiano dos pensadores britânicos do século XVIII. Enquanto Kant afirma que o sublime nos permite intuir a nossa capacidade racional, a versão fisiológica de Burke acerca do sublime envolve uma crítica da razão. O sublime de Burke não é uma questão de incrementar a autoconsciência do sujeito, mas considerar o senso de limitação do sujeito e do valor final dessa experiência dentro de um contexto social e ético (RYAN, 2001: 266).

É corrente a leitura segundo a qual "o conservadorismo de Burke é fundamentado no ceticismo" (KRAMNICK, 1999: 11). Da consciência das limitações inerentes à natureza humana nasce a desconfiança diante de doutrinas seculares subitamente “reveladas": sendo imperfeito, o Homem não pode pretender formatar um sistema político perfeito.

Tal conclusão é constante no pensamento de Burke e de muitos dos conservadores que o sucederam. O veredito conservador para as explicações revolucionárias é invariavelmente cético: trata-se de presunções e utopias, de natureza falsa e perigosa.

A crítica filosófica às utopias que fizeram nascer a modernidade política é inaugurada pela filosofia de David Hume (1711-1776), que buscou mensurar seus alicerces epistemológicos menos visíveis. $\mathrm{Na}$ esteira da dinâmica que rege o pensamento religioso, tais utopias, inebriadas pelo apriorismo, atentariam contra a realidade, cuja fonte é a experiência. Isso "corresponde, em Hume, à sua antipatia pela religião e seu desgosto por todas as formas de entusiasmo político" (QUINTON, 1976: 46). O próprio racionalismo constitui um engodo, afiançado por uma crença tão pouco provável quanto a fé religiosa. Nesse sentido, Hume sustenta que "não se pode conceber como essas qualidades triviais da fantasia, conduzidas por essas falsas suposições, possam alguma vez levar a qualquer sistema sólido e racional" justamente porque o raciocínio dos propagadores das utopias "não tem conexão possível com a existência" (HUME, 2000:250). Na esteira desta lógica, Burke, sem as mesmas restrições à religião,

[...] sublinha o artificialismo racionalista dos philosophes que imaginavam poder criar e destruir governos com a força da vontade e da razão. Segundo Burke, os revolucionários desconheciam os princípios básicos de funcionamento dos verdadeiros corpos políticos. Os Estados são sempre 
criações coletivas e históricas, não podendo ser controlados por homens cuja vida breve não é capaz de acumular a experiência e sabedoria necessárias (ARAÚJO, 2004: 3).

Para Burke, a governança precisa acatar o fato de que a sociedade ser imperfeita. Logo, idealismos devem ceder lugar às práticas longamente testadas pela experiência ofertada pelos antepassados e revoluções fundadas em "revelações" descoladas da realidade exigem ceticismo prudente. A censura burkeana opor-se-ia à "ambição desmedida de atribuir à razão a tarefa hercúlea de construir e reconstruir a sociedade humana de forma radical e perfeita", de modo que "não é a razão per se que inspira a crítica conservadora; é, tão só, a arrogância do racionalismo moderno" (COUTINHO, 2014: 54). A mentalidade conservadora advoga, portanto, que "a verdade prática é encontrada nos costumes e nas tradições. Os verdadeiros legisladores agem por esses impulsos ${ }^{3}$ práticos" (VINCENT, 1995: 81) e não por ideais abstratos.

As doutrinas revolucionárias gestadas no ventre do iluminismo racionalista, pelo contrário, fatalmente incorreriam no erro de desprezar o passado, confiando cegamente na genialidade de arquitetos sociais que difundem ideias de ruptura tão súbitas quanto autogestionadas. De acordo com Burke, os valores sociais se perenizaram no tempo pela sua conexão com a realidade e pela rigidez dos testes que enfrentaram. Tal perspectiva deslegitima a arrogância dos "literary caballers and intriguing philosophers" ou "political theologians and theological politicians" (BURKE apud KRAMNICK, 1999: 419) que forjam ideias novas e sem lastro.

Para o pai do conservadorismo político moderno, doutrinadores que alardeiam o uso da razão como fonte de legitimação das suas propostas seriam, contraditoriamente, absorvidos por uma crença mística nas suas próprias (pseudo)verdades, tornando-se presunçosos e hostis à crítica. A fim de combater as construções axiológicas que sustentam o status quo, os filósofos revolucionários forjariam um sistema de princípios ainda mais arbitrário (além de artificial). O racionalismo transformar-se-ia em abstracionismo, em teologia secular. A alardeada lógica dos tratados científicos cederia lugar ao misticismo dos "literary caballers". Ao conservador, portanto, impõe-se a postura de desconfiança/ceticismo.

\footnotetext{
${ }^{3} \mathrm{O}$ emprego do termo "impulso" é delicado e pode gerar conclusões equivocadas, uma vez que o conservadorismo clássico supõe a moderação e uma prática política baseada na experiência e no respeito a normas longamente testadas (justamente o oposto do comportamento daquele que age por impulso).
} 
Ao avaliar o tema, Karl Mannheim deixa transparecer os elementos que dão fôlego a tal juízo, uma vez que "a tentativa de realização da revolução, por mais planejada e 'científica' que seja, invariavelmente produz um elemento irracional 'milenarista"" (MANNHEIM, 1986: 98). Hannah Arendt, por seu turno, detém-se na reflexão acerca daqueles que consideram que ideologias modernas como o comunismo seriam "uma nova 'religião', não obstante seu declarado ateísmo, por preencher social, psicológica e emocionalmente a mesma função que a religião tradicional preenchia" (ARENDT, 2005: $139)^{4}$. Finalmente, John Gray atesta que "os projetos utópicos” que avançaram durante o século XX, "embora estruturados em termos seculares que negavam a verdade da religião, constituíam de fato veículos para os mitos religiosos" (GRAY, 2008: 11).

Do racionalismo emergiria o irracionalismo e a utopia: uma falsa interpretação do mundo que propõe a construção de um Éden impossível. Sob a ótica de Gertrude Himmelfarb (2004), estão criadas, assim, as condições para o advento do "despotismo esclarecido" fomentado pela intelectualidade da França revolucionária: procurar-se-ia enaltecer a razão para, a partir dos filósofos que a guardam, iluminar o governante e os povos. Em idêntico viés crítico, Leo Strauss pondera que desde Rousseau o racionalismo visava destruir a dualidade Civitas Hominis-Civitas Dei de Agostinho de Hipona, forjando uma religião civil obviamente ditada pelos interesses falíveis dos homens e dos governos (STRAUSS, 1959). Ainda nessa discussão, O’Gorman sintetiza o ceticismo e a oposição ao racionalismo moderno contidos na cosmovisão burkeana, adiantando suas consequências:

Burke deliberadamente optou por manter o papel de crítico do pensamento contemporâneo. Seu pensamento revolucionário limita-se à sua reação à filosofia iluminista da religião, da sociedade e do homem. O Iluminismo provocou profundas ansiedades intelectuais na mente de Burke, o que gerou uma filosofia antirrevolucionária, e esta procedeu de uma posição antiracionalista. A liberdade, por exemplo, não era uma proposição abstrata, mas uma realidade social. A propriedade não devia ser considerada como uma construção mental. Tratava-se, em termos práticos, do baluarte da ordem social. Inevitavelmente, portanto, o anti-racionalismo de Burke reforçou a sua

\footnotetext{
${ }^{4}$ Ainda que os excertos transcritos acima sejam ilustrativos, não se poderia deixar de mencionar o respeitado trabalho de Raymond Aron, O Ópio dos Intelectuais, publicado originalmente em 1955.
} 
presunção duradoura em favor de qualquer governo estabelecido ou instituição existente (O'GORMAN, 2004: 125).

É certo que Burke advoga a manutenção da ordem e dos sistemas políticos tradicionais. Sua justificativa, por um lado, está no respeito à estabilidade erigida pelos hábitos sociais e pela provação do tempo; por outro, baseia-se no temor das ideias salvacionistas e do arbítrio político, que são intrinsecamente avessos à moderação e à prudência cética em matéria de política. Mas não seria acertado enxergar neste pensador um partidário da total imutabilidade social.

O modo como Burke positiva a revolução inglesa ocorrida no século XVII, tema ao qual dedica parte expressiva do seu livro mais importante, robustece essa hipótese. Por que o instituidor do conservadorismo moderno manifestaria tal atitude? Porque, longe de desencadear rompimentos traumáticos, os acontecimentos de 1688 teriam reconduzido a Inglaterra ao berço das suas tradições, ceifando mudanças impensadas (e idealizadas) e realinhando as instituições políticas com os hábitos sociais:

Desejávamos, quando da Revolução, e desejamos ainda derivar do passado tudo o que possuímos, como uma herança legada pelos nossos antepassados. Sobre o velho tronco de nossa herança, tivemos cuidado em não enxertar nenhuma muda estranha à natureza da árvore primitiva. Todas as reformas que até aqui realizamos procedem do princípio de referência à antiguidade (BURKE, 1982: 67).

A deferência de Burke pela "gloriosa revolução" decorre do pendor de permanência (ou restauração) que distinguiu esse movimento. Para ele, a própria tradição eventualmente pode reclamar reformas pontuais que garantam a constância do ethos social já enraizado. Em decorrência disso, o entendimento de Burke julgaria que "algumas reformas podem até ser admitidas, contanto que resultem de um longo processo de experimentação e não de uma ruptura radical com o passado" (COUTINHO, 2011: 9). De fato, naquelas páginas de Reflections on the Revolution in France consta que a revolução inglesa foi totalmente distinta da agitação jacobina, sendo que a primeira teria representado precisamente um aperfeiçoamento do passado, uma nova dose de vitalidade para o então magoado arcabouço institucional que agasalhava as tradições da sociedade anglo-saxônica. 
À margem da temperança dos ingleses seiscentistas, a impetuosidade jacobina nos faria mergulhar em um estado de desordem e tolhimento das liberdades. Porque os homens são imperfeitos, a superação das coerções sociais tradicionais, antes de conduzirnos para um estado de natureza supostamente pautado pela liberdade, ocasionaria chagas e anarquia:

O 'estado de natureza', para Burke, foi um estado de anarquia desumano ao qual o homem não deve optar por retornar. Ele afirmou que as instituições humanas, longe de impor restrições artificiais sobre o homem - como muitos escritores iluministas declararam -, libertou-o da anarquia do estado de natureza e permitiu uma liberdade ordeira para desenvolver suas faculdades (O'GORMAN, 2004: 134).

Por conseguinte, o retorno àquela licenciosidade natural proposta pelos iluministas (e nisso as teses do "bom selvagem" rousseauniano emergem como protagonistas), seria nocivo, uma vez que a bondade/perfectibilidade natural do homem simplesmente não existiria. Fiel a tal pressuposto, Burke escreveria mais tarde: "a sociedade requer [...] que as paixões dos indivíduos possam ser subjugadas [...]. Isso só pode ser feito por um poder que está fora dos indivíduos" (BURKE apud KRAMNICK, 1999: 16). À libertação proposta pelo retorno ao estado natural responde-se com os arranjos já admitidos historicamente pelas sociedades e com o ceticismo frente às rupturas.

Logo, as instituições que validam a ordem política são benéficas desde que brotem da tradição, sejam maturadas por um longo processo de acúmulo de conhecimentos e limitem-se à gestão dos conflitos sociais. Nestes moldes, a imposição da ordem pelo Estado historicamente lapidado, longe de amputar o arbítrio individual (como, aliás, denunciam muitos doutrinadores liberais), produziria a autêntica liberdade e permitiria um convívio social harmonioso, erguido pelo esforço de sucessivas gerações. Em síntese, "a boa ordem é o fundamento das boas coisas. Para ser capaz de adquirir, o povo, sem ser escravo, deve ser manejável e obediente. Os magistrados devem ser respeitados e as leis obedecidas" (BURKE, 1982: 219). A manutenção da ordem e de um padrão de moralidade, princípios eternamente inegociáveis para os conservadorismos, tem aqui uma das suas máximas mais ilustrativas. 


\section{O parlamentar Whig e a reação à revolução francesa}

Após eleger-se para a House of Commons em 1765, Burke iniciou uma nova fase. O labor político passou a absorvê-lo completamente, e seu proselitismo migrou definitivamente da literatura para a tribuna do parlamento. Ainda que seja imperativo ressaltar que Burke jamais tenha exercido papeis de liderança no interior do partido Whig $^{5}$, sua ativa atuação parlamentar fez emergir boa parte dos elementos que estruturariam a filosofia conservadora.

Da tribuna, Burke toma posição veemente acerca da emergência de um levante que definiria para sempre os rumos do pensamento conservador. Em 1789 a França rompia com as tradições: o parlamentar reagiu imediatamente. Seus discursos na House of Commons passaram a ter como pauta privilegiada a revolução jacobina:

Burke tinha agora um novo objetivo: defender o antigo regime na França e na Europa. Para atingir este objetivo era necessário demonstrar que uma mudança política radical não era apenas impraticável, mas, no contexto do Antigo Regime, positivamente indesejável. Burke, portanto, sublinhou o perigo que a inovação e a ruptura podem ocasionar a um sistema social através da introdução de elementos novos e alienígenas [...]. A característica central do pensamento de Burke era a sua preocupação em preservar a velha sociedade (O'GORMAN, 2004: 124).

Na acepção de Burke, a revolução francesa é intolerável, uma vez que sintetiza os ideais iluministas, a aversão ao passado, o triunfo da ideologia sobre os costumes erigidos pelos ancestrais. Ademais, suprime a nobreza e a monarquia pelos "intriguing philosophers", a religião divina pelo abstracionismo alastrado pelos "political theologians", a hierarquia e a ordem pelo igualitarismo antinatural e pelo caos. Nesse sentido, é correta a premissa de que Burke, em última análise, vislumbrava a revolução

\footnotetext{
${ }^{5}$ Apesar disso, é certo que a atuação parlamentar de Burke foi muito influente, uma vez que protagonizou ou esteve presente nos principais debates do Reino Unido de seu tempo. De qualquer forma, O'Gorman (2004: 22) pondera que "embora Burke tenha sido o grande orador desse período, seu talento nunca o fez obter a liderança de seu partido na House of Commons". Não deixa de ser curioso que Burke tenha pertencido ao partido Whig, e não ao Tory, agremiação da qual descende o atual Partido Conservador da Inglaterra. É possível que sua escolha, em parte, decorra da filiação de seu patrono político, o Whig Rockingham.
} 
como "uma ruptura com a civilização europeia" (FURET, 2001: 93). Era imperativo reagir: "a condenação de Burke em relação à Revolução Francesa começa por ser, não uma condenação ideologicamente sistematizada e articulada - mas, precisamente, uma reação" (COUTINHO, 2009).

No entanto, Burke não se contenta em golpear a revolução apenas com as armas da oratória, e em 1790 publica Reflections on the Revolution in France. Se "ninguém foi mais longe do que Burke na defesa e no direito do passado governar o presente, negando, pois, o direito à revolução" (FLORENZANO, 1996: 17), o pensador irlandês não deixaria de se esmerar no uso de adjetivos para caracterizar o movimento jacobino:

Nos últimos tempos estávamos em perigo de sermos presos pelo exemplo da França na rede de um despotismo implacável. [...] Nosso presente perigo está no exemplo de um povo cujo caráter não conhece a ponderação; é, no que diz respeito ao governo, o perigo da anarquia, o perigo de ser levado, através de uma admiração à fraude bem-sucedida e à violência, a uma imitação dos excessos de uma irracional, inescrupulosa, confiscatória, saqueadora, feroz, sangrenta e tirânica democracia. Do lado da religião, o perigo do seu exemplo não é mais a intolerância, mas o ateísmo, uma falta, um vício antinatural, inimigo de toda a dignidade e consolação da humanidade (BURKE, 1982: 139).

Caos, autocracia, confisco e violência emergem como resultados da revolução que solenemente assegurava emancipar a França das amarras do passado. A "tirânica democracia" que brota é antagônica à ilusória utopia contida no lema "liberdade, igualdade e fraternidade". Negando a moderação e o ceticismo diante de novidades repentinas, o terror torna-se uma ferramenta de governo, ergue-se como "vontade presumida" que julgaria, sem prudência, conhecer o bem para os povos, ainda que precise valer-se da violência para promovê-lo.

Ademais, o acontecimento de 1789 teria introduzido a incerteza, em detrimento da segurança ofertada pelo Ancien Régime: "É impossível estimar a perda que resulta da supressão dos antigos costumes e regras da vida. A partir daquele momento não há bússola que nos guie, nem temos meios de saber a que porto nos dirigimos" (idem, 1982:102). O dano às referências causado pela queda da monarquia e de seu conjunto de valores revelava-se especialmente pernicioso para o povo: 
Eu não saberia qualificar a autoridade que atualmente governa na França. Ela se crê uma democracia pura, apesar de eu crer que em breve ela se tornará uma ignóbil e malévola oligarquia. [...] Até o presente nunca tivemos exemplo de democracias dignas de nota. [...] Estou certo que em uma democracia, a maioria dos cidadãos é capaz de exercer, sobre a minoria, a mais cruel das opressões. [...] Acredito que essa dominação exercida sobre a minoria, se estenderá sobre um número maior de indivíduos e será conduzida com muito mais severidade do que, de modo geral, poderia ser esperado da dominação de uma só coroa (BURKE, 1982: 135-136).

Para Burke, a oligarquização da nova facção governante degenerava em métodos políticos que naturalizam a tirania. Vestindo a fantasia da democracia a fim de exercer seus arbítrios, o regime desencadeou uma opressão ainda mais formidável do que aquela supostamente protagonizada outrora pelo rei. La Terreur, fundamentado ideologicamente, se instalava ${ }^{6}$.

\section{Hierarquia, propriedade, comunitarismo e liberdade}

Na perspectiva de Burke, a supressão da monarquia teria determinado mais do que apenas uma violenta distorção política que custou incontáveis vidas, sendo o governo revolucionário responsável por conduzir o povo francês ao esquecimento de normas de conduta moral incrustadas no modus vivendi da comunidade; normas consideradas capitais para qualquer cultura ou hierarquia social. Ao analisar o pensamento de Burke, Araújo sustenta que

A polidez e o cavalheirismo são forças responsáveis por deslocar o indivíduo de sua rudeza egoísta para o seio do organismo social. O bom gosto, elegância e refinamento das classes nobres atuam pedagogicamente sobre o conjunto social, na medida em que despertam afeto e admiração, seguidos pelo desejo natural de imitação. Ao dissolver o bom gosto e a polidez e destruir a nobreza,

${ }^{6}$ J. L. Talmon (1988) cunhou o termo "democracia totalitária" para ilustrar o espírito do governo revolucionário francês, bastante solícito em distribuir a violência durante o período denominado como "Terror". 
a Revolução ameaçava o próprio fundamento das sociedades humanas (ARAÚJO, 2004 :6-7).

Se à nobreza cumpriria a elevação moral do povo, conclui-se que ela seria intrinsecamente superior. De fato, a existência de uma desigualdade natural entre os homens está plenamente assentada no pensamento do irlandês: "Para Burke, os pobres eram ignorantes e numerosos demais para aspirar poder econômico ou político. A desigualdade social não causava nenhum terror a Burke. De fato, isso fazia parte da ordem natural das coisas" (O'GORMAN, 2004: 50) ${ }^{7}$. Propostas de igualitarismo atentam contra a realidade e demandam ceticismo.

Ainda que essa desigualdade seja parte da ordem natural e tenha reflexos diversificados que separariam os homens de acordo com capacidades e responsabilidades inerentemente distintas, sua relação com a propriedade, ao menos para o conservadorismo, é também relevante. Heterogêneos, os homens não poderiam igualarse na conquista e posse de bens materiais. A desigualdade social é habitual e desejável:

A característica essencial da propriedade, formada a partir dos princípios combinados de sua aquisição e conservação, é ser desigual. [...] O poder de perpetuar a nossa propriedade em nossas famílias é uma das circunstâncias mais valiosas e interessantes desse poder, e é isso que permite a perpetuação da própria sociedade (BURKE apud KRAMNICK, 1999: 439).

A essência da propriedade é a desigualdade, que estrutura e mantém o corpo social a partir das competências de cada indivíduo, mesmo porque "todos os homens têm direitos iguais, mas não direito a coisas iguais" (BURKE, 1980: 53). Em vista disso, Florenzano assinala que os pensadores conservadores, a exemplo de "Burke, Tocqueville e H. Arendt, para citar três nomes famosos, consideram que o governo não só nada pode fazer para eliminar a pobreza existente como quando tenta fazê-lo acaba por agravá-la" (FLORENZANO, 1996: 7). Para Burke, “a massa popular deve se contentar com sua

\footnotetext{
${ }^{7}$ O’Gorman não parece ter se detido severamente no conceito burkeano de ordem natural, o que eventualmente pode abrir margem para deduções temerárias. Importa advertir que para Burke o significado da ordem natural não se fundamenta em princípios abstratos. Supõe-se que seria mais prudente ponderar que o pensador irlandês considerou como natural "o que aparece como resultado de um longo desenvolvimento histórico, de um longo hábito; por outras palavras, natureza equivale a história, experiência histórica, hábito criado pela história" (CHEVALLIER, 1966: 190).
} 
posição de natural subordinação. Precisa respeitar a propriedade da qual não pode compartilhar" (O'GORMANN, 2004: 140).

Ainda que semelhante ideia contenha tintas de elitismo, o pensamento burkeano transcende a mera defesa dos interesses de casta. Em face daqueles que conjeturam, mediante uma leitura marxista, que o objetivo inconfessável de Burke seja “advertir a sua própria classe para os riscos que acarretariam a participação popular nos processos de decisão" (MAGALHÃES, 1996), pode-se contrapor o argumento de que o pensador irlandês esposou uma concepção orgânica da sociedade, que exalta a cooperação comunitária de inspiração cristã antes da chamada "luta de classes". Nesse sentido, Maria D’Alva Kinzo assinala que

Estado e sociedade fazem parte da ordem natural do universo, que é uma criação divina. Segundo Burke, Deus criou um universo ordenado, governado por leis eternas. Os homens são parte da natureza e estão sujeitos às suas leis. Estas leis eternas criam suas convenções e o imperativo de respeitá-las; regulam a dominação do homem pelo homem e controlam os direitos e obrigações dos governantes e governados. Os homens, por sua vez, dependem uns dos outros, e sua ação criativa e produtiva se desenvolve através da cooperação (KINZO, 1989: 20).

Com efeito, se Burke eleva certos valores naturais acima das contingências materiais e tem uma visão organicista da sociedade, é questionável transformá-lo em soldado autômato de uma "classe privilegiada". De acordo com Burke e os conservadores de um modo geral, o convívio social forjado em tempos idos basear-se-ia na interdependência e complementaridade entre os diferentes extratos sociais. Nesta ótica, a natureza é desigual; o contrato tácito erigido por Deus e acatado por sucessivas gerações chancela essa disparidade, se harmoniza com o crivo da experiência e deve ser respeitado para o bem de todos. "Exceto em um último senso moral, os homens são desiguais. "A organização social é complexa e sempre inclui uma variedade de classes, ordens e grupos. Diferenciação, hierarquia e liderança são características inevitáveis de qualquer sociedade civil” (HUNTINGTON, 1956: 456), defendem os conservadores. Não seriam os indivíduos iluminados por novas ideias de igualdade os portadores da autoridade necessária para modificar esse arranjo. 
Segundo Burke, a desigualdade não suprime a colaboração e o sentido coletivo em sociedades penetradas pelos princípios cristãos. Nestes casos, a assistência-mútua propicia a segurança e a comunhão entre os homens, que se vinculam em torno de interesses comuns, para além, portanto, das eventuais gradações econômicas que os diferem. Conforme Kinzo conclui, a cooperação "requer a definição de regras e a confiança mútua, o que é desenvolvido pelos homens, com o passar do tempo, através da interação, da acomodação mútua e da adaptação ao meio em que vivem”, criando assim "os princípios comuns que formam a base de uma sociedade estável” (KINZO, 1989: 20). O’Gorman extrai tal perspectiva da obra de Burke:

Não há diferença de interesses entre os ricos e os pobres, porque as iniciativas dos ricos, como administradores dos pobres, como seus protetores e como os seus prestadores, supõem a retirada de uma parcela específica de seus lucros para o cumprimento dessas responsabilidades. [...] Por outro lado, há um contrato implícito, muito mais forte do que qualquer instrumento ou acordo formal, que dita que as condições de remuneração devem ser suficientes para gerar ao empregador um lucro sobre o seu capital e uma compensação para seu risco (O'GORMAN, 2004: 50).

O antídoto à injustiça que eventualmente pode acompanhar a desigualdade está na preservação da cooperação que permeia as relações sociais nos núcleos comunitários, tidos por Burke como exemplo de vida orgânica, cooperativa, ordeira e livre. Dos associativismos nascidos na vida comunitária emerge o sentido saudável da coletividade: “que é o primeiro princípio - o germe por assim dizer - de nossas afeições públicas [...] é o primeiro elo da corrente que nos liga à nossa pátria e à humanidade" (BURKE, 1982: 79). Com efeito, Russel Kirk, outro conservador renomado, segue a receita de Burke: “o verdadeiro conservadorismo nasce como um antípoda do individualismo. Individualismo é atomismo social; conservadorismo é comunidade de espírito. Os homens não podem existir sem sua própria comunidade" (KIRK, 2001: 242).

Ademais, há um valor que subsiste à margem de eventuais clivagens e diferenças sociais: a liberdade como direito primeiro dos homens. Ao contrário do que ocorre em relação ao acúmulo de bens materiais, a liberdade independe das capacidades inerentes de cada indivíduo, ao menos a priori. Nesse sentido, Burke observa: 
Eu certamente creio que todos os homens que desejam a liberdade, merecemna. Não se trata da recompensa ao nosso mérito ou da aquisição gerada pelo nosso esforço. É a nossa herança. É o direito de primogenitura de nossa espécie. Não podemos perder o nosso direito a ele, ou perderíamos os títulos de privilégios da nossa espécie; significaria o abuso ou o esquecimento de nossas faculdades racionais (BURKE apud O'GORMANN, 2004: 158).

Contudo, a liberdade, esse "direito de primogenitura", não se confunde com a inexistência de regras inegociáveis e perenes (porque historicamente enraizadas), nas quais repousaria a verdadeira liberdade coletiva (do contrário, insurgir-se-ia o abstracionismo, que deve ser combatido com ceticismo). Existem freios à liberdade puramente individual:

O governo é uma invenção da sabedoria humana, para providenciar às necessidades dos homens. Em nome de todas essas necessidades, deve convirse que a mais sensível é a de restringir suficientemente as paixões. Nesse sentido, inclui-se a repressão, tanto quanto a liberdade, entre os direitos dos homens (BURKE, 1982: 67).

O governo, diante da imperfeição humana, precisa ser dotado de instrumentos de coerção, a fim de conter as paixões nascidas daquela imperfeição. Por esse prisma, a repressão é bem-vinda quando instrumentalizada de modo a preservar a estabilidade, herdeira legítima dos hábitos sociais históricos. Burke "procura eliminar todo e qualquer direito, e legitimidade, à revolução, à possibilidade de ruptura institucional" (FLORENZANO, 1996: 16).

Para o conservador irlandês, a reforma (e não a revolução) geraria mais belos frutos. Ao refletir sobre o movimento de 1789, considerava que os franceses "teriam feito a causa da liberdade venerável aos olhos dos sábios de todos os países, e desonrado o despotismo aos olhos do mundo inteiro" (BURKE, 1982: 72). Portanto, há o reconhecimento de que o regime carecia de melhoramentos e atentava contra a legítima liberdade pública. Porém, se tivesse renunciado à via revolucionária, a França possivelmente evidenciaria uma importante lição: "não somente a liberdade pode se conciliar com a observância das leis, mas ainda que, quando ela é bem disciplinada, pode fazer respeitar a lei” (idem, 1982: 72). Daí teria surgido uma liberdade fidedigna porque baseada em 
[...] uma Constituição livre, uma monarquia poderosa, um exército disciplinado, um clero reformado e venerado, uma nobreza menos orgulhosa, mas mais digna [...]. É esta felicidade que constitui a única verdadeira igualdade moral entre os homens, e não esta monstruosa ficção que [...] só serve para agravar e para tornar mais amarga a desigualdade (BURKE, 1982: 72).

Outro princípio primordial para o entendimento burkeano em relação à liberdade seria a deferência do Estado não apenas às coisas divinas, mas à plenitude de ação das instituições religiosas no espaço público (a defesa de liberdade de culto dos católicos na Irlanda lhe rendeu amargas críticas por parte de muitos de seus colegas de parlamento). A revolução jacobina teria atentado contra valores inegociáveis:

Desde o início, Burke havia considerado a Revolução Francesa como uma profanação, um assalto ateísta sobre os princípios sagrados da cristandade, uma infecção da ordem moral pelo individualismo racionalista do Iluminismo que atacou as unidades básicas da sociedade: a família, a igreja, a comunidade e as instituições sociais da nação (O'GORMAN, 2004:159).

Tais valores nortearam e ainda norteiam o pensamento e a ação de intelectuais e movimentos conservadores espalhados pelo mundo.

\section{Considerações finais}

Edmund Burke, falecido em fins do século XVIII, foi um emblemático crítico das ideias políticas que se insurgiram contra princípios tradicionais ainda amparados no Ancien Régime. Sua reação, no entanto, não ficou congelada no tempo, de modo que a ideologia por ele inspirada, o conservadorismo, inegavelmente continua viva e atuante, perpetuando-se por meio de livros, discursos e práticas político-comportamentais levados a cabo por intérpretes que se renovam constantemente em praticamente todos os ambientes políticos.

Contudo, a capacidade de adaptação reiteradamente demonstrada pelo conservadorismo - seria mais apropriado, talvez, falarmos em conservadorismos, conforme receita Coutinho (2014) - apenas pontualmente transgrediu as balizas 
filosóficas formuladas por Burke. É verdade que o conservadorismo é bastante plural, passando pelo reacionarismo radical e reversionista de nomes como Maistre e Maurras (reacionarismo que não raro apenas se aproxima dos demais conservadorismos), pela inclinação secular e quase psicológica de Michael Oakeshott, pelas convergências com o liberalismo, e pelo neoconservadorismo, que sem aderir ao reversionismo antissistêmico dos reacionários, considera, por exemplo, que a promoção dos valores morais (às vezes de ordem religiosa) constitui um dever político no âmbito de uma "guerra cultural". Contudo, valores burkeanos como ceticismo político, antirracionalismo, aversão à ruptura/revolução, apreço pela hierarquia, pela ordem, pela propriedade e pela liberdade permanecem presentes nos conservadorismos contemporâneos com o mesmo protagonismo que tiveram no pensamento já bicentenário do parlamentar irlandês.

Por meio do exame das principais obras de Burke, percebe-se que o nascimento do conservadorismo esteve intimamente relacionado com a reação à revolução francesa. Se os efeitos do jacobinismo ainda se fazem sentir, é também verdadeiro que a contraposição conservadora não se limitou às páginas de Reflections on the Revolution in France. Mais do que suprimir uma ordem política, a agitação de 1789 representou, aos olhos de Burke, um golpe formidável às bases mais caras da sociedade tradicional e do pensamento político que lhe antecedeu. Para Burke, a revolução inaugura o império da abstração política, da vontade presumida, das ideias desconectadas com a realidade que impulsionam a tirania.

Daí porque o ceticismo político é um elemento tão crucial para se compreender a obra de Burke e o pensamento conservador como um todo. Apenas os arranjos constantemente submetidos aos testes do tempo e da experiência acumulada pelas gerações passadas - e não uma ideologia revelada - seriam capazes de nortear o bom estadista. Para o founding father do moderno conservadorismo (e para seus herdeiros), a ruptura dificilmente se justifica: justamente por desprezar a tradição, reclama amplo ceticismo de qualquer sociedade sadia que porventura almejasse sua própria preservação.

Às ideias de igualdade, de mudança e de libertação sem freios dos indivíduos Burke contrapõe a hierarquia, a prudência, a defesa da ordem. A realidade - e não as boas intenções baseadas no otimismo antropológico - deveria cimentar a ação política justamente porque o ser humano é imperfeito. A desconfiança e o socorro oriundo das respostas ancestrais têm precedência sobre as ideologias de transformação social. A religiosidade impera sobre o relativismo moral. A comunidade é superior ao indivíduo. 
Se, repita-se, "por paradoxal que possa parecer, o pensamento político da época moderna começa por este conservador" (WEFFORT, 1989:9), não seria de todo heterodoxo aventarmos a possibilidade de que também a proclamada "pós-modernidade" continue sob seu influxo. Certos players políticos não raro validam semelhante hipótese, inclusive no Brasil atual.

\section{Fonte}

BURKE, Edmond (1982). Reflexões sobre a revolução em França. Brasília: Editora da UNB.

\section{Referências bibliográficas}

ARAÚJO, Valdei Lopes (2004). O sublime, o belo e a Revolução: história e narrativização em Burke e Hegel. Rio de Janeiro: Revista Intellectus, vol. 1, n. 3, pp. $1-15$.

ARENDT, Hannah (2005). Entre o Passado e o Futuro. São Paulo: Perspectiva.

CHEV ALLIER, Jean-Jacques (1966). As grandes obras políticas de Maquiavel a nossos dias. São Paulo: AGIR.

COUTINHO, Carlos Nelson (2011) "Prefácio". In: NETTO, Leila E. O conservadorismo clássico: elementos de caracterização e crítica. São Paulo: Cortez, pp. 9-11.

COUTINHO, João Pereira (2014). Conservadorismo. Lisboa: Dom Quixote. (2009). Em busca do Equilíbrio. Dicta e Contradicta, n. 3. Disponível em: $<$ http://www.dicta.com.br/edicoes/edicao-3/em-busca-do-equilibrio/>. Acesso em: 09 set. 2014.

FLORENZANO, Modesto (1996). Thomas Paine Revisitado. Instituto de Estudos Avançados da Universidade de São Paulo. Disponível em: <http://200.144.182.46/publicacoes/textos/florenzanothomaspaine.pdf >. Acesso em: 02 ago. 2015.

FURET, François (2001). A Revolução em debate. Bauru, São Paulo: Edusc.

GRAY, John (2008). Missa Negra. Religião apocalíptica e o fim das utopias. Rio de Janeiro: Record.

HIMMELFARB. Gertrude (2004). The Roads to Modernity: the British, French and American Enlightenments. New York: Vintage Books.

HUME, David (2000). Um tratado sobre a natureza humana. São Paulo: UNESP.

HUNTINGTON, Samuel (1957). Conservatism as an Ideology. Washington: The American Political Science Review, vol. 51, n. 2, pp. 454-473.

KANT, Immanuel (1989). A paz perpétua e outros opúsculos. Lisboa: Edições 70.

KINZO, Maria D’Alva (1989). Burke: a continuidade contra a ruptura. In: WEFFORT, Francisco (Org.). Os Clássicos da Política. São Paulo: Ática, pp. 3-46.

KIRK, Russel (2001). The conservative mind. From Burke to Eliot. Washington: Library of Congress.

KRAMNICK, Isaac (1999). The Portable Edmund Burke. New York: Penguin Books. 
MAGAlHÃES, Fernando (1996). Burke e a formação da Filosofia Política do Liberalismo Conservador. Perspectiva Filosófica, vol. 4, n. 8, pp. 73-96.

MANNHEIN, Karl (1986). O pensamento conservador. In: ARAÚJO, José de Souza (Org.). Introdução crítica à sociologia rural. São Paulo: Hucitec, pp. 84-106.

O’GORMAN, Frank (2004). Edmund Burke: his political philosophy. New York: Routledge.

PARKIN, Carl (1985). Burke e la tradición conservadora. In: THOMPSON, David. Las ideas politicas. Barcelona: Editorial Labor, pp. 121-133.

QUINTON, Antony (1976). The politics of imperfection. The religious and secular traditions of conservative thought in England from Hooker to Oakeshott. London: Faber e Faber.

ROTHBARD, Murray (1958). A Note on Burke's Vindication of the Natural Society. Pennsylvania: Journal of the History of Ideas, vol. 19, n. 1, pp. 114-118.

RYAN, Vanessa Lyndal (2001). The Physiological Sublime: Burke's Critique of Reason. Pennsylvania: Journal of the History of Ideas, vol. 62, n. 2, pp. 265-269.

STRAUSS, Leo (1959). What is Political Philosophy? Chicago: The University of Chicago Press.

STRAYER, Joseph (1986). As origens medievais do Estado Moderno. Lisboa: Gradiva.

TALMON, Jacob Leib (1988). Los orígenes de la democracia totalitaria. Madrid: Alianza Editorial.

VINCENT, Andrew (1995). As ideologias políticas modernas. Rio de Janeiro: Jorge Zahar.

VOEGELIN, Eric (1982). A Nova Ciência da Política. Brasília: Editora da UNB.

WEFFORT, Francisco (1989). Os Clássicos da Política. São Paulo: Ática.

Artigo recebido em 10 de setembro de 2014.

Aprovado em 11 de julho de 2015. 